\title{
The Current Situation and Countermeasure Research of "School Football" in Nanchong City Elementary Schools
}

\author{
Wang Qin \\ College of Physical Education \\ China West Normal University \\ Nanchong City \\ 342199126@qq.com
}

\author{
Zhang Chi \\ College of Physical Education \\ China West Normal University \\ Nanchong City \\ Zhangchi64@126.com
}

\begin{abstract}
In order to know how the "School football" activity organically combine with school physical education teaching, football reserve personnel cultivation and quality education and its important role in comprehensive education, the paper selects eight elementary schools of different levels in Nanchong city as individual cases, and uses qualitative research methods to conduct research from the aspects of selective schools, field, teachers, funding for training and competition. According to results: the distribution of "school football" pilot schools is not balanced in Nanchong, and the teachers, funding, facilities and courses are insufficient, and different levels of football competitions lack of standardization. The paper puts forward some strategies to deal with these issues, providing a realistic basis for relevant functional department to develop strategies, as well as providing reference for the further and effective development of "School football" in other areas.
\end{abstract}

Keywords-Nanchong City; Elementary Schools; School Football; Status; Issues; Strategy

\section{INTRODUCTION}

In order to promote The Decision on Developing Sunshine Sports for Millions of Students, State General Administration of Sport and the Ministry of Education have jointly launched the "school football activities" at more than 2000 schools in 44 cities[1]. After recent ten dark years of football, China enters into the prosperity of football. Currently, youth football receive high degree of attention and concern in football and education circles, meanwhile, with the help of the national competitive development policy and funding, youth football across the country has been developing rapidly; but while "School football" receives a series of achievements, some data and examples also show that "School football" still has many problems and hidden dangers we must pay attention to and reflect on. Nanchong, as one of the national "campus football" model points, its integrated level of many aspects, including culture, economy, live population, public educational level and so on, can reflect other small cities' situation. Meanwhile, the development situation and theory of "School football" in its urban elementary schools also have the representative feature of the development of youth football in other small and medium cities. Therefore, a case study of Nanchong urban primary schools' status of "School football" is representative and universal.

\section{RESEARCH OBJECTS AND METHODS}

\section{A. Research Objects}

Select different levels of schools as the survey sample, including traditional football schools: Nanchong Xihe Road Elementary School; Nanchong youth campus football pilot schools: China West Normal University Affiliated Elementary School, Nanchong Sanyuan Experimental School, and Nanchong Five-star Elementary School. General elementary schools: Nanchong Fujiang Road Elementary School, Xishan Foreign Language Experimental Elementary School, Nanchong Gaoping First Elementary School, Spark Elementary School in Jialing district.

\section{B. Research Methods}

-Interviewing method, through field trips, have face-to-face conversations with physical education teachers, parents and students, and get the most authentic first-hand data.

-The literature method, consult relevant policy documents and study relevant research results by looking through the periodical literature in China National Knowledge Infrastructure, relevant state policies in official web site, master's thesis or doctor's thesis and so on.

- The practice method, learn about the integral situation of college football development through campus visits, taking an active part in the teaching and training and competition activities in football research schools.

- Logical analysis method, collect, analyzes and infers related gathered documents and date..

\section{ANALYSIS AND DISCUSSION}

A. Football teachers of elementary schools 
TABLE I. Professional Football TEACHERS OF NANCHONG City ELEMENTARY SCHOOLS

\begin{tabular}{|l|c|c|c|}
\hline \multicolumn{1}{|c|}{ School Name } & Regular & $\begin{array}{c}\text { Part- } \\
\text { time }\end{array}$ & $\begin{array}{c}\text { Cooperation } \\
\text { with football } \\
\text { clubs }\end{array}$ \\
\hline $\begin{array}{l}\text { The China West Normal } \\
\text { University Affiliated Elementary } \\
\text { School }\end{array}$ & 0 & 1 & 0 \\
\hline $\begin{array}{l}\text { The Nanchong Sanyuan } \\
\text { Experimental School }\end{array}$ & 2 & 0 & 1 \\
\hline $\begin{array}{l}\text { The Nanchong Five-star } \\
\text { elementary School }\end{array}$ & 0 & 1 & 1 \\
\hline $\begin{array}{l}\text { The Nanchong Xihe Road } \\
\text { Elementary School }\end{array}$ & 0 & 0 & 1 \\
\hline $\begin{array}{l}\text { The Nanchong Fujiang Road } \\
\text { Elementary School }\end{array}$ & 1 & 0 & 0 \\
\hline $\begin{array}{l}\text { The Nanchong Gaoping First } \\
\text { Elementary School }\end{array}$ & 0 & 0 & 1 \\
\hline $\begin{array}{l}\text { The Xishan Foreign Language } \\
\text { Experimental Elementary School }\end{array}$ & 0 & 0 & 1 \\
\hline $\begin{array}{l}\text { The Spark Elementary School in } \\
\text { Jialing district }\end{array}$ & & 1 & 1 \\
\hline
\end{tabular}

From the date of table I, we can see that the football professional teachers in elementary schools are in short supply in Nanchong, that each elementary school owns a professional football teacher on average cannot be guaranteed; except some schools hiring outside professional football coaches, more schools choose to hire football coaches of the local football clubs, such as Magnolia Football Club, and the coaches in the club are all teachers from physical education college of China West Normal University or students of professional football major.

\section{B. Football facilities at elementary schools}

TABLE II. FOOTBALL FIELD AT NANCHONG ELEMENTARY SCHOOLS

\begin{tabular}{|l|c|c|c|c|}
\hline \multicolumn{5}{|c|}{ Plastic fake grass football field in Nanchong elementary schools } \\
\hline & 5 & 7,8 persons & $\begin{array}{c}11 \\
\text { persons }\end{array}$ & Small area \\
\hline $\begin{array}{l}\text { The China West } \\
\text { Normal University } \\
\text { Affiliated } \\
\text { Elementary School }\end{array}$ & 0 & $\begin{array}{c}1 \text { (plastic } \\
\text { flat) }\end{array}$ & 0 & 0 \\
\hline $\begin{array}{l}\text { The Nanchong } \\
\text { Sanyuan } \\
\text { Experimental School }\end{array}$ & 0 & 0 & 1 & 0 \\
\hline $\begin{array}{l}\text { The Nanchong Five- } \\
\text { star elementary } \\
\text { School }\end{array}$ & 0 & 1 & 0 & 0 \\
\hline $\begin{array}{l}\text { The Nanchong Xihe } \\
\text { Road Elementary } \\
\text { School }\end{array}$ & 0 & 0 & 0 & 1 \\
\hline $\begin{array}{l}\text { The Nanchong } \\
\text { Fujiang Road } \\
\text { Elementary School }\end{array}$ & 0 & 0 & 0 & 1 \\
\hline $\begin{array}{l}\text { The Nanchong } \\
\text { Gaoping First } \\
\text { Elementary School }\end{array}$ & 1 & 0 & 0 & 0 \\
\hline $\begin{array}{l}\text { The Xishan Foreign } \\
\text { Language } \\
\text { Experimental } \\
\text { Elementary School }\end{array}$ & 0 & 1 & 0 & 0 \\
\hline $\begin{array}{l}\text { The Spark } \\
\text { Elementary School in } \\
\text { Jialing district }\end{array}$ & 0 & 1 & 0 & 0 \\
\hline
\end{tabular}

According to the research, Nanchong City elementary school has a fairly limited number of the football fields, and specification is not consistent (according to table II). According to research, the Sanyuan Experimental School often divides the 11-person standard football field into two fileds. Several football model schools in Nanchong city, and some traditional football project schools and general primary schools cannot expand sports filed because they are located in the downtown area, letting the development of school football be restricted by fields. Besides, I learn that the number of football in every school is small by interviewing with physical education teachers, having about 30-50 training balls(with poor quality), 10 football logo barrels, 20-50 logo disks, and 20 sets of football team clothing.

\section{The football class hours in Nanchong elementary schools}

In sports class teaching, each school could ensure a football class a week, but the teaching model and standard are not consistent. Some schools' sports education class has football equipment, but the teaching content cannot guarantee the real study of football project, usually use football to play games or letting students play football on their own. According to the statistics on students' questionnaire, only a few students select "be able to play football", less than one-fourth, and students selecting "have football interest" are less than one-tenth. Meanwhile, the arrangement of football teaching materials also are very different. Though having purchased the football textbooks, the arrangement on the specific teaching content is highly arbitrary and random. In addition, in some schools which have relatively good condition, the phenomenon that the graduating class' sports class is occupied by other major subjects still exists.

In extracurricular football interest classes and training, researched schools have opened football interest classes and training courses at different levels (details are shown in table III, table IV)

TABLE III. FOOTBALL INTEREST CLASS IN NANCHONG ELEMENTARY SCHOOL

\begin{tabular}{|l|l|l|l|l|}
\hline & 2 times & 3 times & 4 times & 5 times \\
\hline $\begin{array}{l}\text { The China West Normal } \\
\text { University Affiliated Elementary } \\
\text { School }\end{array}$ & & & & $\sqrt{ }$ \\
\hline $\begin{array}{l}\text { The Nanchong Sanyuan } \\
\text { Experimental School }\end{array}$ & & & & $\sqrt{ }$ \\
\hline $\begin{array}{l}\text { The Nanchong Five-star } \\
\text { elementary School }\end{array}$ & & & & $\sqrt{ }$ \\
\hline $\begin{array}{l}\text { The Nanchong Xihe Road } \\
\text { Elementary School }\end{array}$ & & & $\sqrt{ }$ & \\
\hline $\begin{array}{l}\text { The Nanchong Fujiang Road } \\
\text { Elementary School }\end{array}$ & & & $\sqrt{ }$ & \\
\hline $\begin{array}{l}\text { The Nanchong Gaoping First } \\
\text { Elementary School }\end{array}$ & & & & \\
\hline $\begin{array}{l}\text { The Xishan Foreign Language } \\
\text { Experimental Elementary School }\end{array}$ & $\sqrt{ }$ & & $\sqrt{ }$ & \\
\hline $\begin{array}{l}\text { The Spark Elementary School in } \\
\text { jialing district }\end{array}$ & & & & \\
\hline
\end{tabular}

Note: the time of interest football class is about 40 minutes- 60 minutes at a time 
TABLE IV. FOOTBALL TRAINING TIME IN NANCHONG CITY ELEMENTARY SCHOOLS

\begin{tabular}{|c|c|c|c|c|c|c|c|}
\hline \multicolumn{8}{|c|}{ Football training schedule } \\
\hline & Mon. & Tues. & Wed. & Thur. & Fri. & Sat. & Sun. \\
\hline $\begin{array}{l}\text { The China West } \\
\text { Normal University } \\
\text { Affiliated Elementary } \\
\text { School }\end{array}$ & 0 & 1 & 0 & 1 & 1 & 1 & 1 \\
\hline $\begin{array}{l}\text { The Nanchong } \\
\text { Sanyuan } \\
\text { Experimental School }\end{array}$ & 1 & 0 & 1 & 0 & 1 & 1 & 1 \\
\hline $\begin{array}{l}\text { The Nanchong Five- } \\
\text { star elementary } \\
\text { School }\end{array}$ & 1 & 0 & 1 & 0 & 1 & 1 & 1 \\
\hline $\begin{array}{l}\text { The Nanchong Xihe } \\
\text { Road Elementary } \\
\text { School }\end{array}$ & 0 & 1 & 0 & 1 & & & \\
\hline $\begin{array}{l}\text { The Nanchong } \\
\text { Fujiang Road } \\
\text { Elementary School }\end{array}$ & 0 & 1 & 0 & 1 & & & \\
\hline $\begin{array}{l}\text { The Nanchong } \\
\text { Gaoping First } \\
\text { Elementary School }\end{array}$ & 0 & 1 & 0 & 1 & 0 & 1 & 1 \\
\hline $\begin{array}{l}\text { The Xishan Foreign } \\
\text { Language } \\
\text { Experimental } \\
\text { Elementary School }\end{array}$ & 1 & 0 & 1 & 0 & 0 & 0 & 0 \\
\hline $\begin{array}{l}\text { The Spark } \\
\text { Elementary School in } \\
\text { jialing district }\end{array}$ & & & 1 & & 1 & & \\
\hline
\end{tabular}

Note: each football-training course for 60 minutes -90 minutes, weekend intensive footbal courses for 90 minutes-120 minutes

According to the table date, Nanchong urban elementary school's football interest class and training class opening times is better, especially in model schools, Through interviewing with school leaders and the responsible person of "campus football" policy implementation, we can learn that this phenomenon is related to the hard-and-fast rule of "campus football" promotion to schools, meanwhile, other Nanchong urban elementary schools also carry out measures under the supervision of functional departments.

\section{The expenses of extracurricular football class in Nanchong elementary schools}

TABLE V. FOOTBALL TRAINING FEE IN NANCHONG ELEMENTARY SCHOOLS

\begin{tabular}{|l|c|}
\hline & Extracurricular football training fee \\
\hline $\begin{array}{l}\text { The China West Normal } \\
\text { University Affiliated Elementary } \\
\text { School }\end{array}$ & $600 \mathrm{RMB} / \mathrm{semester}$ \\
\hline $\begin{array}{l}\text { The Nanchong Sanyuan } \\
\text { Experimental School }\end{array}$ & $600 \mathrm{RMB} / \mathrm{semester}$ \\
\hline $\begin{array}{l}\text { The Nanchong Five-star } \\
\text { elementary School }\end{array}$ & $600 \mathrm{RMB} / \mathrm{semester}$ \\
\hline $\begin{array}{l}\text { The Nanchong Xihe Road } \\
\text { Elementary School }\end{array}$ & $300 \mathrm{RMB} / \mathrm{semester}$ \\
\hline $\begin{array}{l}\text { The Nanchong Fujiang Road } \\
\text { Elementary School }\end{array}$ & $300 \mathrm{RMB} / \mathrm{semester}$ \\
\hline $\begin{array}{l}\text { The Nanchong Gaoping First } \\
\text { Elementary School }\end{array}$ & $450 \mathrm{RMB} / \mathrm{semester}$ \\
\hline $\begin{array}{l}\text { The Xishan Foreign Language } \\
\text { Experimental Elementary School }\end{array}$ & $20 \mathrm{RMB} / \mathrm{time}$ \\
\hline $\begin{array}{l}\text { The Spark Elementary School in } \\
\text { jialing district }\end{array}$ & $20 \mathrm{RMB} / \mathrm{time}$ \\
\hline
\end{tabular}

According to interviews with school sports education teacher, it can be informed that Nanchong urban primary school football extra-curricular interest classes and football practice costs, apart from schools' nominal subsidy, charge different consumable fees and training fees on the basis of the students' training times according to the use of equipment and the need of teacher training subsidy; the physical education teachers who responsible for related works are also helpless about the payment. They said it is to make contributions to some extent. And this is also the important reason that school extracurricular football activities become a mere formality. This problem is consistent with the problems in other local school football work[2].The interview with parents of students shows that they have no complaints about the charges, and they think the standard of fee is appropriate and reasonable, and their family economic income also can bear.

\section{E. Extracurricular football games}

Since the beginning of 2015, each semester has pupils Football League in Nanchong city. For example, the Nanchong Sanyuan Experimental School has class league each semester. There is the Nanchong City Summer Camp Football League in summer holiday, and the Nanchong City Winter Camp Football League in winter holiday; each district also has football league, such as pupils football league in Shunqing District, Magnolia Club School Football League; there are exchange matches of training teams organized by physical education teachers in different schools. Through watching, organizing contest and investigating responsible person of contest, it is learned that many unfair issues which happen in professional competitions have emerged in games with slightly higher levels, such as "black whistle" and "match-fixing".

\section{SUGgestions}

\section{A. Solve the problem of football teachers shortage by combining independent cultivation and outward introduction}

With the development of Nanchong economy and the implementation of preferential policy promoting small city to development. Nanchong makes great progress and development in economy, and culture and the traffic aspects. However, due to long-term poverty and limitation of geographic position, the talent introduction of all kinds of schools is not optimistic; therefore, if school wants to solve the problem of "school football" teachers shortage, except strengthening talent introduction efforts, more effective method is that schools independently cultivate physical education teachers to solve the immediate problems through effective methods such as "send them out to learn" and "hire football professional teachers of local university to conduct training".

\section{B. Supply football playground by the use of school playgrounds and the lease of other training fields}

For the schools that cannot be expanded in Nanchong city, they should plan the sports field, build some football fields, buy outdoor sports equipment (such as removable basketball, removable table tennis table, and so on), which makes football field also be basketball and volleyball courts, allowing limited 
facilities to support a variety of sports activities. Meanwhile, for schools that cannot effectively provide football standard training and training field, they can lease social gymnasium free of charge or with certain costs to guarantee the development of football training and games under the support of related government departments.

\section{Hold the bottom line of "school Football" with the initial} concept and purify the environment of "school football"

"School Football" not only bears the education tasks, but also undertakes the duty of realizing national fitness and the historical mission to become a world sports power. Therefore, the development of "School Football" should finish the football teaching goals in content and form, focus on "health first" in football class and carry out funny football activity [3]. It should also strengthen the cultivation of students' football interests by extracurricular physical activities according to the actual situation of students in Nanchong City (compelling students to accept football is not desirable), and combine Sunshine sports with school football[4]. More importantly, scientifically and sustainably cultivate and train students who have interest in football[5], and standardize the grass-roots football games, put an end to the problem of "physical quality is better, but thoughts slip back", really achieving the purpose of cultivating students' interests, establishing their concept of lifelong exercise, and letting them develop morally, intellectually and physically through playing football. Achieve improvement of football after the popularization and play a positive role in the cultivation of football talents.

The situation of "School Football" development in Nanchong elementary schools is mixed, weekly football class is random in content and form, the tutorship of interest class tends to form to a large extent, the standard and science of football training need to be improved. There are some uncivil behaviors in football games, such as uncivil executive conference or "match-fixing". In addition, one football lesson in a week whether to make students command football technology efficiently or obey the concept of "people-oriented" is a deliberate question (this to say whether to respect the majority of the students ' interest in sports).

\section{CONCLUSION}

"School Football" prompts football movement to develop in Nanchong urban elementary schools' PE class and extracurricular sports exercise. The organization and implementation of grass-roots football game get wide support of related functional departments, school, parents and the social organization. It has cultivated some students' interest in football; but there are also some problems, for example, the content and form of football teaching are random, interest class becomes formalistic to some extent, and the scientificity of football training and the standardability of grass-roots football game need further improvement. Meanwhile, "School Football" has enormous developing space in quality education and comprehensive education; it is also the core content of the new round of top design of "School Football" and one of the essential issues that must be taken into account in reconstruction of the new mechanism [6].

\section{REFERENCES}

[1] Dong Zhongming, Gong Bo, Yan Zhongjie. Discussion on Problems of Football Activities on Campus, Journal of Shanghai University of Sport, Vol.35, pp.91, Mar 2011(in Chinese)

[2] Chu Qihui, the Condition and Countermeasure of Elementary and Middle School Football Teachers under the Background of College Football ,Henan University, 2014,pp.26(in Chinese)

[3] Liang Wei, System Analysis and Evaluation of Sustainable Development of College Football, Shanghai University of Sports, 2015, pp.138 (in Chinese)

[4] Zhang Tingan, The View of Scientific Development in Future Development of College Football in Our Country should Be Establish, Journal of Beijing University of physical education, Vol.38, pp.108, Mar 2015(in Chinese)

[5] Zhang Tingan, The View of Scientific Development in Future Development of College Football in Our Country should Be Establish, Journal of Beijing University of physical education, Vol.38, pp.110, Mar 2015(in Chinese)

[6] Mao Zhenming, Liu Tianbiao, and Zang Liuhong, About "New College football" Top Design, Journal of Wuhan Institute of Physical Education, Vol.49, pp.58, Mar 2015(in Chinese) 